\title{
Př́íčiny a logika sebevražedného terorismu podle Roberta A. Papea. Kritické uvedení do jedné ambiciózní teorie*
}

\author{
KAREL ČERN Ý** \\ Causes and Logic of Suicide Terrorism according to Robert A. Pape: \\ Critical Introduction into an Ambitious Theory
}

\begin{abstract}
The paper focuses on a long-term research project and findings of R. A. Pape who deals with root causes of suicide terrorism. Pape has elaborated the largest suicide terrorist attacks database (1980-2010) and a theory of suicide terrorism based on it. His approach consists of three levels of analysis: organizational (strategic), social (community), and individual logic. The terrorism pattern consists of a rational strategy, that is part of an asymetric conflict with an occupying power which is a democratic state, that is not willing to negotiate. Finally, there must be a religious difference between the two adversaries. The article also discusses the main criticism of the theory.
\end{abstract}

Keywords: suicide terrorism; occupation; religious difference; Robert A. Pape; strategic logic

DOI: $10.14712 / 23363525.2017 .25$

Když jsme vstoupili do Libanonu, žádný Hizballáh tam nebyl. Šiité na jihu nás vítali rýží a květinami. Byla to naše dalši přitomnost, co stvořilo Hizballáh.

Ehud Barak, izraelský ministr obrany ${ }^{1}$

Afghánští vesničané nás př̀ patrolách zvali domủ na čaj i večeře. Pak jen pozdravili. Jak se noční razie v jejich domovech množily, prestali zdravit. A najednou byly na cestách spousty bomb. Vypiplali jsme Taliban i tam, kde predtím nebyl.

Americký zelený baret ${ }^{2}$

\section{Úvod}

Cílem přehledové stati je kriticky představit teorii sebevražedného terorismu, s níž přišel americký politolog Robert A. Pape. Přitom identifikoval tři roviny reality hodné samostatné analýzy a pět faktorů-determinantů sebevražedného terorismu. Ambiciózní model vypracoval poté, co sestavil historicky první databázi všech sebevražedných teroristických útoků i podpůrnou databázi sociodemografických profilů jejich pachatelů.

\footnotetext{
"Studie vznikla v rámci projektu GAČR č. 13-35717P Strukturální přičiny arabských revolucí a nástupu politického islámu řešeného na Fakultě humanitních studií Univerzity Karlovy v Praze.

** Mgr. Karel Černý, Ph.D., Pracovišš historické sociologie, Fakulta humanitních studií, Univerzita Karlova, U Kř́žze 8, 15800 Praha 5 - Jinonice. E-mail: karlos.cernoch@post.cz.

1 Podle [Pape 2010: 198].

2 Rozhovor autora, Santa Barbara, USA, 2012.
} 
Ačkoliv jde o předního badatele s originálním přístupem $\mathrm{k}$ aktuální problematice, Pape je v českém prostředí prakticky neznámý. Například T. Raděj [2006: 257; 2010: 189] ho $\mathrm{v}$ přehledovém textu o islámském sebevražedném terorismu uvádí jen v poznámce pod čarou mylně jako autora „výborné demografické sondy“. Podobně E. Souleimanov [2010: 46] se na Papea v reprezentativní knize Terorismus: Pokus o porozumèní odvolává zkreslujícím způsobem, který jde proti skepsi Papea ohledně prioritní role náboženství a fanatismu: „Ve jménu Bohem sankcionovaného násilí je ztráta vlastního a nepřítelova života považována za vrcholné štěstí. Mučednictví je nejjistější cestou do ráje - teroristický útok je bohulibým aktem násilí, kdežto mučednická smrt má sakrální význam, nebot činí člověka nesmrtelným. “ A v tomtéž odstavci uzavírá, že je pseudonáboženský terorismus iracionální, jakkoliv Pape forsíruje racionalitu aktérů teroru.

Naopak věrně, leč stručně Papea představil J. Eichler [2006: 38; 2009: 469-470]. A to jako realistu se státocentristickým přístupem, který zdůrazňuje, že nacionalistické pohnutky převažují nad motivy náboženského fundamentalismu. Terorismus je nástroj, jenž usiluje o to, aby stát čelící útokům přehodnotil svou politiku a byl donucen k ústupkům. Připomíná, že al-Kajda neudeřila na žádný stát, který se nenechal zatáhnout do americké politiky vůči islámskému světu. Systematičtější a kritické uvedení raného Papea [2003] do českého prostředí pochází též od Z. Hesové [2010]. Nacionalistická logika atentátů je podle Hesové nejpřesvědčivější v situacích okupace. Hůře prý vysvětlí útoky na muslimy z jiné sekty v situaci občanské války (Irák), v př́padě globálního teroru al-Kajdy pak o nacionalistickém motivu hovořit nelze. Hesová se také kloní k alternativní hypotéze o tzv. trumfování [viz Bloom 2005], vysvětlující nasazení sebevražedných útoků proti okupantovi jako taktiku soupeřících hnutí o moc a podporu uvnitř okupované populace. O odpor vưči okupantovi má jít až v druhém plánu. Konečně, Hesová v rozporu s Papem chápe útoky al-Kajdy ve světě jako „symbolické, postrádající zjevný politický cíl“. Stejně tak sebevražedný terorismus v Kašmíru, Kurdistánu nebo Čečensku neklasifikuje jako nacionalistický, ale separatistický. V českém prostředí tak více než deset let chybí nezkreslené a detailnější seznámení s touto propracovanou teorií, přičemž absentuje i její systematičtější kritika.

Pape si za to nicméně může částečně sám. Zpočátku [Pape 2003, 2006] totiž budil dojem akademického solitéra a své bádání nezasazoval do kontextu dalších teoretických a empirických výzkumů. Vymezoval se pouze proti několika raným studiím [např. Reich 1990; Kramer 1990; Merari 1990] a stereotypům žurnalistů. Budovanou teorii sytil sběrem a analýzou empirických dat, ne studiem prací kolegů. Na ostatní badatele reagoval dodatečně, jen pokud ho kritizovali [např. Kramer 2005; Moghadam 2006; Ashworth - Clinton - Meirowitz - Ramsay 2008]. Přičemž ale metodologii i teoretické explanace v reakci na kritiky revidoval. Ignorování dalších odbýval tak, že je sebevražedný terorismus nesouměřitelný s tím konvenčním, aniž by vysvětlil, v čem ona specifičnost vězí [srov. Pape 2006: 8-24]. Do intenzivnějšího dialogu s kolegy vstoupil později, když pracoval na př́padových studiích [Pape 2010; viz Černý 2015]. A když v Chicagu kolem své databáze založil celou školu produkující analýzy testující nejrůznější hypotézy [např. Benson 2014; Jordan 2014].

Kromě neochoty Papea přihlásit se k nějaké teoretické tradici o terorismu je obtížnost jeho zařazení dána také eklektickým charakterem teorie, jež se snaží o komplexní zachycení zkoumaného fenoménu pomocí kombinace hned několika teoretických východisek. 
Autor má nicméně nejblíže k tradici chápající terorismus jako racionální strategii k dosahování politických cílů. A to kalkulujícím aktérem, jenž se nachází v mocensky výrazně asymetrické pozici vůči protivníkovi [např. Fromkin 1975; Friedland - Merari 1985; Lake 2002]. Odmítá tak psychologizování i další monokauzální teorie spatřující příčiny terorismu v chudobě, kultuře, náboženském fanatismu, indoktrinaci či odcizení. Přitom zdůrazňuje legitimizační roli náboženského rozdílu protivníků a mobilizační roli nacionalismu, čímž se blíží dalšímu originálnímu teoretikovi pracujícímu s oporou v celoživotně sbíraných rozhovorech, M. Juergensmeyerovi [1993, 2000, 2008].

Jestliže se tedy jedná o nejambicióznějšího, politicky vlivného a mimořádně provokativního teoretika sebevražedného terorismu, programově bořícího četná klišé stran sebevražedného terorismu, v českém prostředí není dostatečně znám a zhodnocen. Cílem přehledové stati proto bude nejprve představit tři analytické roviny a pět faktorů Papeova teoretického modelu. Poté se zaměříme na podrobnou kritiku primárně strukturovanou podle tř́ rovin samotné teorie. Přitom zdůrazníme genezi a zpřesňování teorie. Přitom identifikujeme autorovy inspirace, teoretické perspektivy a metodologické postupy. A to vše zasadíme do kontextu dalších výzkumů terorismu.

\section{Od databáze $\mathrm{k}$ teorii}

Pape a jeho Chicago Project on Suicide Terrorism (CHPOST) vytvořil první kompletní databázi sebevražedných útoků z let 1980-2009 (2188). V letech 2010 až 2016 do databáze přibylo dalších 2935 sebevražedných útoků. Shromáždil i biografická a socioekonomická data o pachatelích z let 1980-2009 (2668), jakkoliv tato podpůrná databáze není úplná. A vše poté transparentně zpř́stupnil (dostupné on-line: http://cpost.uchicago.edu). S pomocí (1) statistických analýz databází (časové řady), (2) kvalitativního rozboru diskursu teroristických organizací i jejich protivníků a (3) podrobných př́padových studií jednotlivých konfliktů Pape formuluje zobecnění v podobě komplexní teorie příčin sebevražedného terorismu.

Ačkoliv se sebevražedný terorismus vyskytuje v různých náboženských, kulturních, ideologických a sociálních kulisách, lze podle Papea [2006] identifikovat společný vzorec. Jedná se o (1) racionálně kalkulovanou metodu asymetrického boje, kdy se slabší strana konfliktu protivníkovi nadále nedokáže efektivně postavit konvenčnějšími prostředky. Sebevražedné operace se stanou součástí již probíhajícího násilného odporu (neozbrojené povstání, guerillová válka) vůči (2) okupaci cizí armádou. A to pouze v situacích, kdy je okupant (3) demokratickým státem kontrolujícím - s použitím síly nebo hrozby jejího použití - teritorium pokládané teroristy za vlast a (4) není ochoten jednat či ustoupit, přičemž obě strany náleží k (5) rozdílné náboženské tradici. Sebevražedný terorismus je tedy reakcí na okupaci, avšak ne vždy okupace ústí v terorismus. Pape [2006: 98-101] totiž napočítal 58 okupací ze strany demokracií (1980-2003). Kampaně ale vznikly jen tam, kde nejprve vypukl násilný odpor proti demokratickému okupantovi odlišného náboženství. Tato konstelace nezávislých proměnných vysvětluje zrod kampaně ve 49 př́padech. Sedmkrát kampaň nevznikla (Morové na Filipínách, menšiny v Indii, muslimové v Thajsku, Belfast). Rozhodující byla ochota okupanta vyjednávat a nabídnout ústupky.

Nejde tedy o teorii opírající se o jeden explanační faktor, ačkoliv okupace působí nejsilněji. Pape nalézá vysvětlení v konstelaci a kumulaci pěti faktorů působících na třech 
úrovních reality, jež se řídí vlastní samostatnou logikou: (1) organizační či strategická logika organizací racionálně sledujících politický cíl (konec cizí kontroly či okupace) a poptávajících rekruty; (2) sociální logika komunit trpících okupací, které tento cíl podporují, ačkoliv váhají ohledně vhodných prostředků odporu, přičemž odlišné náboženství okupantů zesiluje pocit ohrožení komunity; (3) individuální logika altruistických jedinců motivovaných účastnit se sebevražedné mise a ochotných nabídnout život jako obět národní komunitě skrze teroristické organizace poptávající mučedníky a konstruující jejich kult.

Pape při budování teoretického modelu pracujícího s konstelací pěti faktorů spolu-působících na třech rovinách sociální reality zároveň systematicky vyvrací dosud populární, leč starší a jednodušší monokauzální explanace sebevražedného terorismu, chytající se do pasti jednoho faktoru [např. Reich 1990]. Jeho obecná kritika upozorňuje, že zatímco jsou sebevražedné kampaně vysoce proměnlivé v čase i prostoru, monokauzální explanace marně vysvětlují vysoce variabilní závislou proměnnou (výskyt sebevražedné kampaně) relativně konstantními nezávislými proměnnými (psychologické patologie, chudoba, nevzdělanost, náboženství). Hovoří proto shodně s dalšími autory o vícekauzálních a komplexních kořenech teroru [srov. Hoffman 1995; Horgan 2005; Ibánez 2009].

Na základě jakých dat a trendů tedy Pape teorii vytvářel? Jak vypadá empirická realita, již se snaží teoreticky vysvětlovat? Zatímco konvenční terorismus vrcholil s 666 útoky v roce 1988 a od té doby ustupuje (348 útoků v roce 2001), frekvence sebevražedného terorismu naopak roste. Od průměrných tř́i útoků ročně v 80 . letech vzrostla na deset misí v 90. letech, aby mezi 11. zárím 2001 a útokem na Irák (2003) vyskočila na průměrných padesát. A poté frekvence velmi rychle vyšplhala o dalších $500 \%$ až na tři sta útoků ročně (2004-2009). Na této vysokých hodnotách se s průměrem 419 ročních útoků výskyt drží dodnes (2010-2016). Zatímco tedy svět během čtvrtstoletí před invazí do Iráku (1980-2003) zažil 350 sebevražedných útoků, z čehož jen $15 \%$ cílilo na USA, během následujících šesti let (2004-2009) došlo k 1833 útokům, z nichž $92 \%$ směřovalo proti americkým cílům. Sebevražedný teror přitom vyniká destruktivností [Pape 2010: 2-10]. V průměru si totiž jeden sebevražedný útok (1980-2003) vyžádal 12 obětí3 , konvenční naopak ani ne jednu [Pape 2006: 28].

Kromě frekvence sebevražedný teror expanduje i geograficky, ačkoliv se stále koncentruje v několika málo zemích: nejprve Libanon (1980-1999), Srí Lanka (1987-2009), indický Paňdžáb (1993-2000)4, Palestina (1994-2008) a Turecko (PKK, 1996-1999), později Čečensko (od 2000), Kašmír (od 2001) a především operace al-Kajdy (od 1995) soustředící se nejen na Saúdskou Arábii, nýbrž i na „vzdálené nepřátele“. Avšak „válka s terorismem“, vyhlášená po 11. září 2001, sebevražedné útoky neeliminovala. Dosud nejničivější kampaně totiž zasáhly po zahraniční vojenské intervenci Afghánistán (470 útoků v letech 2001 až 2009, do roku 2016 dalších 667), Irák (v letech 2003 až 2009 přes 1000, do roku 2016 dalších 987), Pákistán (v letech 2003 až 2009 přes 200, 2010 až 2016 dalších 278). Ale menšinově i Uzbekistán (6 útoků v letech 2004-2009) či Somálsko (dosud 127 útoků v letech 2006 až 2016) [Pape 2010: 27]. Nejnovější drtivé kampaně vznikly v Sýrii (v letech 2011 až 2016 dosud 280 útoků), Nigérii (2011 až 2016179 útoků) či Mali (24 útoků od roku 2013)

\footnotetext{
3 Bez započtení útočníků a po vyřazení „odlehlého pozorování“ (11. září 2001). Nejnovější údaje pro léta 2010 až 2016 hovoří o průměrných devíti obětech na jeden útok [CPOST 2016].

4 Série čtyř útoků, z nichž tři byly neúspěšné $(1993,1999,2000)$ a jeden úspěšný (1995).
} 
a oproti předchozím letům masivně zesílila již probíhající kampaň v Jemenu (první útok z roku 2000, v letech 2008 až 2016134 útoků) [CPOST 2016].

\section{Strategická logika organizací: Reakce na okupaci armádou demokratického státu}

Pape [2006: 23] sebevražedný terorismus pokládá za „extrémní strategii boje za národní osvobození používanou proti armádám demokratických zemí, které okupují teritorium pokládané za vlast“. Většina sebevražedných útoků (přes $95 \%)^{5}$ není izolovaných či náhodných. Jsou naopak součástí pečlivě naplánované série či shluku. Tedy kampaně s jasným začátkem a koncem, jejíž součástí je i formulování a připomínání politických požadavků. Takové kampani předchází eskalace násilného konfliktu vedeného různými prostředky: neozbrojené povstání, guerilla, konvenční terorismus ${ }^{6}$. K taktice sebevražedného terorismu se slabší strana asymetrického konfliktu uchyluje jako k poslední možnosti, když je převaha výrazně silnějšího protivníka zřetelná a dosavadní způsoby odporu se vyčerpaly a ukázaly jako neefektivní či nedostatečné.

Kampaň je zároveň vždy součástí konfliktu politického, v jehož jádru je spor o kontrolu cizí armádou okupovaného či ohrožovaného teritoria, jež je teroristickou organizací pokládané za vlast nacházející se v existenčním nebezpečí. Podle Papea [2003] teroristické organizace vesměs usilují o dva cíle: o podporu kauzy nebo o zastrašení protivníka. Rovnováha mezi oběma cíli je u různých organizací různá. Demonstrativní terorismus se snaží o publicitu a skrze ní o získání aktivistů z vlastní populace, sympatií umírněných ze znepřátelené populace i prrízně třetí strany. Chce, aby se hodně lidí dívalo. Nikoliv, aby hodně lidí umíralo. Naopak destruktivní terorismus spoléhá na donucení a zastrašení maximalizací škod a utrpení. I za cenu ztráty příznivců sympatizujících s jejich kauzou. Sebevražedný terorismus Pape řadí k destruktivnímu pólu. Chápe ho jako krajní strategii, jež má nepřátelské vojsko přimět k odchodu, a docílit tak národního sebeurčení, nezávislosti a pocitu bezpečí. Jakkoliv se někdy útočí i na civilisty, hlavním terčem kampaně bývají ozbrojené složky reprezentující cizí moc a prosazující na „národním“ teritoriu její politiku. Nacionalistický cíl kontroly a správy národního území je tedy důležitější než motiv náboženský [Pape 2003].

Pape [2006: 98-109] tedy chápe okupaci poněkud široce: jako politickou kontrolu teritoria cizí skupinou, jíž se domácí obyvatelstvo cítí ohroženo. Okupace ovlivňuje politický vývoj teritoria, čehož dosahuje vojenskou silou či hrozbu jejího použití. Klíčová je tedy percepce: mezi domácím obyvatelstvem převládající definice „okupace“ a „okupanta“

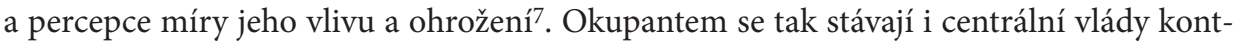
rolující s pomocí armády teritorium etnických menšin s ambicemi dosáhnout autonomie či nezávislosti (Srí Lanka, indický Paňdžáb, turecký Kurdistán). Nebo dokonce armády dislokované v sousední zemi, avšak chápané jako bezprostřední celoregionální ohrožení (USA v Saúdské Arábii). Ještě problematičtější je podle mého názoru rozšíření definice

5 Zbylými útoky se Pape nezabývá, neklade si ambici je teoreticky vysvětlit [2006: 39].

6 Výjimkou byla kampaň proti okupačním jednotkám v Iráku, jež propukla zároveň s povstáním sunnitů. Odchylkou je pak kampaň al-Kajdy na Arabském poloostrově namírená proti americkým cílům a marně se snažící rozdmýchat rebelii proti „okupantům“ i vládě.

7 Vede se tak vlastně dvojí konflikt o definici situace: kdo je terorista (bojovník za svobodu vs. terorista) a co je okupace (stabilizační/demokratizační intervence vs. imperiální vměšování / existenční a kulturní ohrožení). 
okupace zavedením pojmu nepř́má okupace, což je vojenský a ekonomický tlak na vládu ústící v nadřazování zájmů cizí země nad zájmy národní [Pape 2010: 19-23]. Výsledkem je kontrola vlády zahraniční mocností (pákistánské vojenské operace v Severozápadním pohraničí po roce 2006 na nátlak USA; přechodná somálská vláda instalovaná po intervenci etiopské armády nepř́mo podporované Američany v roce 2009). Různé „loutkové“ vlády instalované po vojenské intervenci (Afghánistán, Irák) či držící se u moci s podporou velmoci a její deklarované ochoty nasadit na její obranu armádu též reprezentují nepř́ímou okupaci (USA a spřátelené arabské diktatury).

Statistická evidence ukazuje, že všechny sebevražedné kampaně (95 \% útoků) z let 1980-2003 svým načasováním reagovaly na okupaci cizí armádou. Stejný vzorec se opakuje i na datech z let 2004-2009, kdy ke kampaním (98 \% útoků) dochází bezprostř̌edně po rozmístění zahraničních jednotek na teritoriu pokládaných teroristy za vlast nebo za jinak symbolicky hodnotné. Přitom celých $92 \%$ útokủ vyprovokovaly operace USA a jejich spojencủ, ačkoliv cílem války s terorismem byl pravý opak [Pape 2010: 9-30] ${ }^{8}$.

Strategická logika je dále doložena tím, že teroristické organizace kampaně ukončí v okamžiku, kdy dosáhnou deklarovaných cílů v podobě stažení okupantů. Sebevražedný terorismus se poté nepřelévá do jiných zemí či regionů. Hizballáh tak nikdy nezaútočil na americké a francouzské cíle po stažení jejich vojsk z Libanonu (1984). Stejně tak přestal se sebevražednými útoky proti Izraeli po ukončení izraelské okupace Libanonu (2000), nepronásledoval Izraelce za hranice. Také palestinský Hamás a Islámský džihád ukončily dílčí kampaně po stažení izraelské armády z Gazy (1994) a Západního břehu (1995) i po požadovaném propuštění šejcha Jasína (1997). Tamilští tygři zase přerušili kampaň po dobu př́měří (1993-1994 a 2001-2003), kdy byla vláda ochotná vyjednávat. Podobně ale organizace ukončují kampaň, je-li vyhodnocena jako neefektivní (kurdská PKK 1999, Sikhové v Paňdžábu 2000). Nebo ji dočasně přeruší, ztrácejí-li podporu národní komunity (Čečensko 2005-2006) [Pape 2006].

Souvislost mezi okupací a sebevražednými útoky dokládá nejen databáze útokủ, nýbrž i evidence $\mathrm{z}$ databáze samotných teroristů. $\mathrm{V}$ naprosté většině totiž pocházejí ze země, jež je obsazena či bezprostředně ohrožena cizí armádou. Nejde tedy o převážně globální či nadnárodní fenomén (v letech 1980 až 2009 pocházelo ze zahraničí jen 10 \%), ale „většina útočí pár kilometrů od domova“. Vesměs se rekrutují z regionů a komunit okupované země, které jsou cizí armádou obsazené (jižní Libanon, okupované zóny Západního břehu a Gazy, Afghánistán). Nikoliv z těch, odkud se vojska stáhla či tam nebyla [Pape 2010: 43].

Mezičlánkem prokázané statistické souvislosti mezi okupací a teroristickou kampaní je čtení reality aktéry obou zneprátelených stran, kteří podle svého chápání situace činí strategická rozhodnutí a svým jednáním ovlivňují další prủběh konfliktu. Přičinný vztah okupace a teroristické kampaně, jakožto i racionální kalkul organizací, proto autor dokládá s pomocí diskurzivní analýzy jejich projevů, kdy je téma okupace cizí armádou vždy ústředním motivem ospravedlňujícím násilí. Například Otevřený dopis Hizballáhu (1985) postuluje za hlavní cíl organizace ukončení cizí okupace (Izrael) a novodobého kolonialismu (Francie, USA). Motiv okupace se od začátku objevuje také v klíčovém prohlášeních

8 Pape [2006: 59; 2010: 332] ale neodhalil korelaci mezi násilností okupace (počet obětí na 1000 obyvatel) a frekvencí terorismu. Kampaním též nezabrání „nízký profil“ cizích vojsk: nepočetnost a dislokace mimo centra osídlení, minimalizace kontaktů s místními, ostentativní respekt k místní kultuře, důraz na lítost po zabití civilistů. Strategie byla použita v Zálivu, především S. Arábii. Přesto došlo k odporu al-Kajdy. 
Hamásu, Prvním komuniké (14. 12. 1987): „Intifáda našeho lidu je výsledkem odmítnutí okupace a s ní souvisejícího útlaku, konfiskací půdy a osadnictví. Osadníci musí vědět, že náš lid zná obětování se pro druhé a mučednictví. Musí pochopit, že násilí plodí jen násilí a že smrt zakládá jen na další smrt.“ Podobně hovoří i Charta Hamásu (1988): „Pokud nepřítel obsadí muslimská území, potom se džihád a boj s nepř́itelem stává individuální povinností každého muslima.“ Také čečenské útočnice (2003) zdůrazňují, že „ženy mučedníků neakceptují ponižování a život v ruské okupaci“. Mimo muslimský svět vưdce Tamilů Velupillai Prabhakaran na oslavách Dne mučedníků prohlašuje: „Pokračujeme v boji za vyhnání nepřátelských sil, které okupují naši posvátnou půdu“ [Pape 2010: 31-32]. Také primárním deklarovaným cílem al-Kajdy je skoncovat s cizí okupací a vměšováním do záležitostí arabského světa. Bin Ládin vyhlásil v Declaration of War Against the Americans Occupying the Two Holy Places (1996): „Lid islámu trpí agresí a nespravedlností ze strany sionisticko-křižácké aliance. Od smrti Proroka jde o největší agresi v podobě okupace dvou posvátných okrsků - samotných základů př́bytku islámu. Útoky v Rijádu a al-Khobár byly varováním. Po víře v Boha není důležitější povinnosti než vytlačit americké nepřátele z posvátných míst Arábie. "Podobně po útocích v Madridu (2004) bin Ládin Evropě nabídl ukončit terorismus, pokud se stáhne z Iráku a Afghánistánu: „Přestaňte prolévat naši krev a my přestaneme prolévat tu vaši“ [tamtéž: 54,57].

Pape při analýze organizační logiky implicitně vychází z teorie racionální volby. Teroristické organizace i jejich protivníci dle něj jednají jako homo economicus, principy ekonomického světa fungují i v tom neekonomickém [pro teorii viz Keller 1997]. Obě strany konfliktu racionálně sledují své zájmy: vypudit okupanta z vlasti, nebo naopak kontrolu cizího území udržet. Přitom hledají nejefektivnější strategie, které minimalizují náklady a maximalizují výnosy. Hnutí odporu zjištují, že takovou strategií jsou sebevražedné kampaně, protože s relativně malými náklady dosahují velkého efektu (v porovnání s dosavadní guerillou, neozbrojenými protesty či konvenčním terorismem). Jejich cílem je zvrátit rovnici na straně okupanta tak, aby v jeho očích náklady na další okupaci převýšily užitek plynoucí z pokračování v okupaci. Jak se nechal slyšet Mahmud al-Zahar, šéf Hamásu v Gaze (1995): „Musíme poměřovat náklady a př́nosy pokračování ozbrojených operací. Pokud bychom našich cílů mohli dosáhnout nenásilně, uděláme to. Násilí je jen prostředek, ne cíl. Izrael nikdy neuznáme, ale příměří je možné na dny, měsíce, roky“ [Pape 2003: 6]. Typická je zde argumentace, že politické metody selhaly a nelze než se uchýlit k násilí: „Sionistický nepřítel nerozumí jazyku proseb a ústupků. Ty jen zvyšují jeho agresivitu a aroganci. Rozumí jen jazyku džihádu, odporu a mučednictví. “ Také sekulární Abdel Karim z Brigád mučeníků od al-Aksá (Fatah) zdůrazňoval strategické myšlení (2002): „Cílem je zvýšit ztráty v Izraeli do bodu, kdy začne izraelská veřejnost požadovat stažení z okupovaných území v Gaze a na Západním břehu. “Fathi Shiqaqi z Islámského džihádu zase s oblibou prohlašoval (1995): „Mučednictví je realistickou volbou v konfrontaci se silnější stranou. Pokud nemůžeme dosáhnout rovnováhy sil, dosáhneme alespoň rovnováhy strachu. "Naprosto stejnou logiku postuluje i šéfideolog al-Kajdy, Ajman Zawahírí v prohlášení Rytíri pod praporem Proroka: „Nepř́iteli musíme způsobit maximální oběti, protože to je jediný jazyk, kterému Západ rozumí. Jedině to nepřítele odradí od další brutality, arogance a ignorování všech tabu a zvyklostí.“ Ospravedlnitelný se organizacím sebevražedný terorismus jeví právě proto, že díky své efektivitě minimalizuje oběti. Podle Tamilských tygrů (1997) je „cílem způsobit maximum škod s minimem ztrát na životech“. Tento paradox odvozovaný od 
smrtící efektivity vyzdvihl i vůdce Prabhakaran: „Tamilský stát můžeme vytvořit za sto let. Ale s použitím sebevražedných operací Černých tygrů zkrátíme lidské utrpení a státnosti dosáhneme dřive." Podobnou logiku vyjádřil i ajatolláh Fadlalláh z Hizballáhu (1985): „Sebevražedné operace jsou ospravedlnitelné, pouze pokud přinesou takovou politickou nebo vojenskou změnu, která je přiměřená oběti jedince, jenž své tělo promění v bombu“ [Pape 2006: 32, 73, 124, 193].

Pape při analýze organizační logiky implicitně navazuje na svůj výzkum (ne)efektivity leteckého bombardování (a také sankcí) při vynucování politických ústupků (Německo a Japonsko za 2. světové války, Korea, Vietnam, Irák), publikovaný v knize Bombing to Win [1996]. Terčem bombardovacích kampaní bývá infrastruktura i obytné čtvrti. Kalkuluje se s podlomením morálky vyděšených civilistů a se ztrátami na životech i majetku, jejich hodnota převýší potenciální zisky plynoucí z pokračování ve válce. Tato manipulace zisků a ztrát má nepřítele zastrašit a donutit ke změně jednání a podřízení se požadavkům 9 . Sebevražedný terorismus [Pape 2006] je tak analogií strategického bombardování či sankcí. Efektivita donucování je v prŕípadě sebevražedného terorismu dána tím, že je (1) destruktivní více než terorismus konvenční. Dále (2) signalizuje ochotu vygradovat konflikt za jakákoliv dosavadní měřítka ignorováním pravidel a překračováním tabu. A demonstruje odhodlanost (3) přinést nejvyšší oběti z vlastních řad. Teroristy je proto obtížné zastrašit hrozbou odvety; jsou připraveni umírat. Signalizují tím vysokou pravděpodobnost budoucích útoků. Nejde totiž jen o aktuální škody a zničení konkrétního cíle. Ale o přesvědčování protivníka, že je zranitelný sérií budoucích útoků. A může tedy očekávat další ztráty, pokud chování nezmění.

Relativně vysokou účinnost kampaní Pape [2003: 10] vyčíslil na 50 \%. Sedm z třinácti ukončených kampaní z let 1980-2003 totiž koreluje se změnou politiky protivníka. Pro srovnání, účinnost sankcí či vojenských intervencí je asi třetinová. Nejjednoznačnějším př́padem byl útok Hizballáhu na americká a francouzská kasárna v Bejrútu (1983), po němž obě armády odešly. Prezident Reagan v pamětech (1990) přiznává vliv útoku: „Cena, kterou jsme museli platit v Bejrútu, byla př́liš vysoká. Tragédie v kasárnách byla otřesná. Museli jsme se stáhnout. Nemohli jsme zůstat a riskovat další sebevražedný útok na mariňáky. "Problém hodnocení účinnosti sebevražedného terorismu je však ten, že $\mathrm{k}$ němu dochází paralelně s konvenčním terorismem či guerillovou válkou. Je pak těžké odlišit relativní vliv jednotlivých metod na rozhodování protivníka. Za druhé, k ústupkům vesměs dochází, nejsou-li tím ohroženy klíčové bezpečnostní a ekonomické zájmy či územní integrita. Hodnota škod vzniklých současným i odhadovaným budoucím terorismem se poměřuje s hodnotou případných ústupků. Pro USA bylo např́iklad nasazení v Libanonu pouhou humanitární misí bez geopolitického významu. Sebevražednému terorismu se ale nedaří prosazovat ambicióznější cíle. Za třetí, silnější strana může ústupky snadno jednostranně revokovat: stažené jednotky opět rozmístit, příměří či jednání přerušit [Pape 2003 $]^{10}$.

\footnotetext{
9 V dokumentu The Fog of War [2003] líčí stratég amerického bombardování Japonska i Vietnamu Robert McNamara záměrné zapálení dřevěného Tokia zápalnými pumami (1945). Během 24 hodin uhořelo sto tisíc civilistů, více než při útocích jadernými pumami. Cílem měsíční kampaně se stala všechna velkoměsta, zahynulo 800 tisíc Japonců, převážně civilistů. Je si jist, že pokud by USA válku prohrály, stanul by před soudem za zločiny proti lidskosti namísto lidí zodpovědných za holocaust a rozpoutání války.

10 Pape [2010] proto s ohledem na limity kampaní nově hovoří o limitovaném donucení.
} 
Racionalita pak spočívá i v tom, že se organizace učí z chyb i úspěchů, často metodou pokusu a omylu (Tamilští tygřri například každý útok nahrávají a analyzují, manuály al-Kajdy obsahují kapitoly „naučené lekce“). Kromě toho se učí od sebe navzájem. Právě jiholibanonské údolí Bekaa se v 70. a 80. letech stalo prvním „inkubátorem“, kde se od Hizballáhu učily Palestinci i Tamilové. Zásadní v procesu učení je poznání, že se sebevražedný terorismus vyplácí. Každý racionální aktér totiž v budoucnu opakuje jednání, které se již v minulosti osvědčilo. To je důvod, proč se od 80. let 20. století šírí a uchylují se k němu další skupiny. Přitom úspěch Hizballáhu při vypuzení vojáků supervelmoci a poté i Izraele je dodnes citovaným př́kladem efektivity sebevražedné metody od Tamilů přes al-Kajdu po Hamás a Islámský džihád, jehož představitel Ramadan Shallah (2001) typicky prohlásil: „Ostudné porážky Izraele v jižním Libanonu a stažení jeho armády nebylo dosaženo u jednacího stolu, nýbrž na bojišti, a to skrze džihád a mučednictví" [Pape 2006: 73].

Jestliže jsou všechny sebevražedné kampaně reakcí na okupaci cizí armádou, ne všechny okupace ústí v sebevražedný terorismus. Terčem se stávají jen demokracie ${ }^{11}$. Jde opět o racionální volbu, protože jsou chápané jako „měkké“. Předpokládá se, že jsou zranitelnější než diktatury, kde díky cenzuře kampaně nezískají publicitu. Nemohou tak zastrašovat obyvatele, kteří navíc neovlivňují rozhodování vlády. Naopak demokratická veřejnost má nízký práh tolerance utrpení i ekonomických nákladů spojených s pokračováním okupace. Zároveň disponuje schopností skrze volby a občanskou společnost ovlivňovat politické rozhodování, a vynutit si tak stažení svých vojáků. Terorismus je proto zaměřen na trestání voličů, kteří jsou chápáni jako spoluodpovědní za okupaci. Navíc se předpokládá, že se demokracie nebudou brutálně mstít na civilistech. Afghánci se tak neuchýlili k sebevražedným misím proti okupaci SSSR, později vůči USA ano. Podobně Kurdové kampaní vyvíjeli tlak na vládu demokratického Turecka, nikoliv však na brutálnější Irák [Pape 2006: 38-60].

\section{Sociální logika: Podpora komunity, kult mučednictví a náboženský rozdíl}

Teroristé podle Papea [2006] vesměs nestojí na okraji společnosti. Nejde o odcizené radikály či menšinové extremisty izolované od umírněné většiny odsuzující násilí. Bez podpory komunity by totiž organizace nedokázaly sebevražedné kampaně delší čas udržet. Potřebují stálý přísun dobrovolníků, ale hlavně souhlas a materiální podporu komunity. Organizace proto mají spíše „vysoký profil“. Každý zná kontaktní osoby, nikdo je však nesmí prozradit okupantovi. Součástí komunitní podpory proto bývá i nesmlouvavá likvidace kolaborantů. Teroristé se vesměs rekrutují ze středu komunit, a to řádově týdny před útokem. Nebývají dlouhodobými a ideologicky vyhraněnými členy organizace (vyjma PKK a Černých tygrů).

Na této rovině analýzy se Pape [2006: 79-167] teoreticky nejvíce blíží sociálnímu konstruktivismu. Ještě důležitější než realita objektivní je ta subjektivní. Tedy v komunitě převažující způsob interpretace a chápání reálného světa (například přítomnost cizí armády / vliv na vládu pochopené jako prrímá/neprrímá okupace) ${ }^{12}$. Teprve to, jak se objektivní svět

11 Výjimkou se může stát Rusko. Od začátku čečenské kampaně (2000) přechází od částečně demokratického k nedemokratickému režimu. Srí Lanka a Turecko jsou dle Freedom House částečně demokratické.

12 Je irelevantní, jak se vidí okupant („mírové sbory“, „demokratizační mise“). Odtud také „boj o srdce a mysl“ lokální populace, jenž bývá strategií okupanta. Propaganda je součástí konfliktu o definici reality. 
subjektivně odráží v myslích, ovlivňuje jednání. Přičemž tyto definice světa vesměs přebíráme od lidí z komunity, jimž důvěřjueme [srov. Keller 1997; Berger - Luckmann 1999].

Jestliže v komunitě existuje konsenzus ohledně cíle v podobě vypuzení okupanta, ještě to neznamená schvalování sebevražedných útoků jako legitimního prostředku k dosažení onoho cíle. Nutná je (1) démonizace a konstrukce hrozivého obrazu všemocného a všeho schopného okupanta, jenž je kontrastován s (2) vyzdvihovanou pozitivní hodnotou ohrožené vlasti či národa, pro jehož obranu se (3) vytvoří vlivný kult mučednictví ospravedlňující sebevražedný teror dvojí redefinicí dosavadních tabu: vraždy jako oprávněného aktu nutné sebeobrany a sebevraždy jako chvályhodné oběti pro dobro komunity.

Teprve prosadí-li se v komunitě takovéto čtení světa, prosadí se i sebevražedné kampaně. Rozhodující roli přitom $v$ kontextu okupace hraje náboženství. Nikoliv však konkrétní náboženská tradice (např́klad islám vykládaný jako „náboženství meče“). Nýbrž libovolný náboženský rozdíl mezi okupantem a okupovaným národem, jakkoliv přitom mohou být obě skupiny výrazně sekularizované. S výjimkou kurdské PKK totiž byly všechny sebevražedné kampaně mířeny na okupanta pocházejícího z odlišné náboženské tradice. Pape [2006: 94] tak svou koncepci nazývá nacionalistickou teorií sebevražedného terorismu: „Cizí okupace ze strany demokratické země posiluje již existující národní cítění díky náboženskému rozdílu znepřátelených skupin. To vede $\mathrm{k}$ podpoře mučednictví ústící $\mathrm{v}$ sebevražedný terorismus."

Okupace vyzdvihne a zdůrazní hodnotu vlasti, jejích dějin a kultury. Tu si komunita v mírových dobách tak ostře neuvědomuje, pokládá ji za samozřejmou a nezpochybnitelnou. Priority a hodnoty jsou ale v radikálně změněné situaci radikálně přeskupeny. Dochází tak k mobilizaci kolektivní a historické paměti i kolektivních emocí s touto pamětí spjatých. A součástí znovuobjevování národní historie a identity bývá právě i upnutí se k náboženské tradici národa, jež má být zachráněna pro př́ští generace. Dále, sociální normy odvozované od tradičních náboženství vždy tabuizují a zapovídají vraždy i sebevraždy. To platí v době míru, avšak v době ohrožení dokáže náboženství redefinovat vraždu jako spravedlivou sebeobranu. A sebevraždu jako mučednictví přinášející obět s cílem ochránit komunitu, jež se nachází v zoufalé a bezvýchodné situaci. Jak Pape [2006: 189] konstatuje: "Okolnosti okupace v reálném světě určují, jak budou interpretovány náboženské normy.“ Např́klad Tamilští tygři se prezentují jako sekulární marxisté („jdeme za náboženství), avšak své mučedníky oslavují ve „svatyních“ s květinami a olejem, odvozených od svatyní hinduistických. Mučedníci v komunitě získají prestiž, protože se obětovali pro „posvátný cíl“: svobodu a nezávislost lidu. Jejich sochy a pomníky stojí na veřejných místech. Každoročně jsou připomínáni národním svátkem Dne hrdinů odkazujícím na první útok legendárního kapitána Millera (5. července 1987). Jižní Libanon zase své mučedníky oslavuje názvem ulic nebo všudypř́tomnými plakáty. Jejich poslední dopisy či videa se obracejí na komunitu. Cirkulují v ní a stávají se z nich hrdinové a vzory hodné následování. Také mučedníci v Paňdžábu se těší podpoře širší sikhské komunity („naši chlapci“), přičemž se o totéž uchází i al-Kajda, odvolávající se na náboženskou povinnost „každého muslima účastnit se džihádu ve jménu Boha a očistit tak vlast (Arabský poloostrov) od okupantü“ (bin Ládin a jeho Declaration of War against the Americans Occupying the Land of the Two Holy Places, 1996).

Okupant vždy redistribuuje vitální zdroje (půda, voda, ropa) na úkor okupovaných. Co jedna strana získá, druhá ztrácí. Hraje se hra s nulovým součtem, kdy nelze dosáhnout 
spokojenosti a prosperity všech. Navíc snaha okupanta podřídit si obyvatelstvo a kontrolovat teritorium zasahováním do stále dalších sfér života plodí odpor i mezi těmi, kteří proti okupaci dosud nevystupovali. Zlomová je situace, kdy je okupant pochopen jako natolik (1) silný a zároveň natolik (2) kulturně odlišný, že jeho přítomnost ohrožuje národní identitu, kulturní dědictví i samo přežití komunity. Čím více shodných nebo alespoň podobných kulturních atributů okupovaných s okupantem, tím slabší pocit ohrožení a následně i nižší ochota znevolněné komunity rebelovat a uchýlit se $\mathrm{k}$ sebevražednému terorismu. Pokud jsou naopak skutečné či domnělé kulturní rozdíly významné, strach z neznámého a odlišného, pocit ohrožení i pravděpodobnost sebevražedných misí roste. Skupinová soudržnost a identita („my“) se totiž nejlépe definuje v protikladu k odlišným skupinám („oni“). Právě vojenská okupace oběma stranám poskytne extrémní př́ležitost negativně se vymezit vůči nepř́iteli, zveličit odlišnosti a naopak potlačit to společné.

$\mathrm{V}$ podmínkách okupace bývá náboženství nejsnáze po ruce vůdcům hnutí odporu při ustavování symbolických hranic se znepřátelenou skupinou a při formování národní identity. Na rozdíl od jazyka je totiž náboženská identita exkluzivní: lze hovořit jazykem komunity i okupanta, avšak nelze zároveň vyznávat obě náboženství. Ke zdůrazňování náboženského rozdílu se tak uchylují i jinak sekulární aktéři (marxističtí Tamilští tygř̀i se strachují o hinduistické chrámy, sekulární Izraelci jsou ochotni ukončit okupaci Gazy spíše než Jeruzaléma). Přitom je okupant s pomocí náboženství démonizován. Brutalita nepřítele je vysvětlována tím, že je mravně méněcenný. Nezná totiž pravdu, jeho náboženství je primitivní, méněcenné, agresivní a eticky pochybné. Tato dehumanizace okupanta založená na negativní interpretaci jeho náboženství však následně zvyšuje ochotu zabíjet. A kult mučednictví ochotu přitom zemřít. Výsledkem je komunitní podpora sebevražedných misí.

Náboženství nehraje roli samo o sobě. Začíná ji hrát až v kontextu okupace. Pape v logice sociálního konstruktivismu novátorsky upozorňuje, že nejde pouze o reinterpretaci vlastní náboženské tradice v duchu mučednictví. Nebo jen o oprášení a vyzdvižení tradičních duchovních hodnot vlasti, v jejímž jménu pak stojí za to zemřít a přitom pozabíjet druhé. Ani nejde jen o interpretaci světské reality pochopené jako okupace, jež vyžaduje mobilizaci náboženství za účelem obrany. Pape totiž novátorsky ukazuje, že okupace stimuluje hned dvojí interpretaci náboženství. Nejen toho vlastního, chápaného pozitivně. Ale především cizího náboženství okupanta vykládaného negativně jako příčina okupace a zdroj ohrožení. Právě sekulární odbojové skupiny se mohou zdráhat interpretovat vlastní náboženství jako motiv odporu. Ani sekularistům však nedělá problém demaskovat náboženství nepřítele jako pravý motiv jeho okupace a agrese.

Například Sikhové v indickém Paňdžábu podle Papea [2006] pochopili zrušení regionální samosprávy a zavedení mimořádných pravomocí centrální vlády a všudypř́itomné armády (1983) jako systematickou snahu hinduistů zlikvidovat náboženství Sikhů. Zejména poté, co armáda spustila operaci Blue Star (1984), na jejímž konci bylo zničení nejposvátnějšího Zlatého chrámu. Strach z hinduismu vytvářeli i místní hindští nacionalisté z hnutí Arya Samaj. Dělali dojem, že se s pomocí centrální vlády chopí moci nad Sikhy. Menšinoví Tamilové na Srí Lance zase chápou politiku vlády většinových Sinhálců jako motivovanou buddhismem. Vládní podpora migrace Sinhálců na tamilská území a zemědělská reforma přidělující jim tam půdu je dle nich skrytou kulturní genocidou. Navíc ústava (1972) udělala z buddhismu státní náboženství. Zdůrazňuje se jeho národotvorná 
role, takže jsou hinduističtí Tamilové z národa vylučováni. Jsou tak diskriminováni v politice, státní správě i ekonomice. Obávají se buddhistických radikálů z řad vlivných duchovních, kteří sabotují mírová jednání. Buddhisté se prý pokládají za vyvolené a nadřazené Tamilům. Sinhálské legendy údajně hovoří o tom, že Budha pobýval na tamilském severu ostrova. A proto je náboženským úkolem buddhistů tamní tradici a zvláštní status ostrova i národa uchovat, přičemž Tamilové se mají podřídit a rezignovat na svou kulturu.

Hizballáh zase dle Papea vydával židovské náboženství za příčinu izraelské okupace Libanonu. Izrael prý není tolerantním sekulárním státem. Ale státem náboženským s obyvatelstvem fanaticky sešikovaným za doktrínou judaismu. Ten motivuje expanzi s cílem vytvořit biblický Velký Izrael. V jeho hranicích od Nilu až po Eufrat se plánují židovské osady. Pro bezbranné muslimy zde nebude místo, morálně méněcenní židé je jako barbaři - či rovnou jako vtělení dábla - postupně vyvraždí. Až poté na zemi sestoupí očekávaný mesiáš. Podobně Al Kajda vidí zahraniční politiku USA jako motivovanou křestanstvím, jen jako poslední kolo křížových výprav s cílem obsadit Svatou zemi. Američané svými intervencemi rozparcelují silné muslimské státy na malé a slabé: Irák na tři, Saúdskou Arábii na čtyři. Následně vytvoří biblický Velký Izrael jako nejsilnější stát regionu. Interpretace islámu sice hraje roli. Ale důležitější je, jak muslimové v kontextu každodenní cizí okupace interpretují náboženství okupanta, tedy judaismus či křest’anství [Pape 2006: 79-167].

\section{Individuální logika: Altruistický motiv}

Osobní motivy k účasti na sebevražedné misi podle Papea [2006] nemají nic společného s běžnými sebevraždami. Ačkoliv tímto klišé o sebevražedných atentátnících přemýšlíme, protože se s běžnými sebevraždami setkáváme častěji a nedokážeme si tak extrémní čin jinak vysvětlit: mají deprese a problémy, nechtějí dál žít, hledají únik, a tak se dají na teror. Nebo prý pro zvrácené hodnoty odmítají život a milují smrt či jde o devianty, zločince, psychopaty a sektářské radikály stojící na okraji umírněné společnosti, která je nepřijímá a nerespektuje. Avšak Pape [2006: 171-198] na individuální rovině analýzy produktivně aplikuje klasickou typologii sebevražd E. Durkheima [1966]. Teroristé jsou altruisté, kteří se obětují pro svou komunitu podobně jako vojáci pro svou jednotku či vlast.

Podle Durkheima [1966; srov. Keller 2001] je egoistická (1) sebevražda způsobena kombinací sociální izolace a osobní krize jedince, se kterou mu pak nemá kdo pomoci. Absenci podpory od druhých provází absence pocitu zodpovědnosti za druhé, což je další vazba držící člověka nad vodou. Sociální regulace lidí v individualizované společnosti je tedy oslabován absencí sociálních vazeb ústící v osamocení. Anomická (2) sebevražda je dána naopak sníženou hodnotovou regulací jedince, kdy se hroutí dosavadní hodnotové a normativní systémy, jež však nejsou dostatečně rychle nahrazovány novými. Lidé tak ztrácí orientaci a vodítko pro stanovování aspirací a následné hodnocení úspěšnosti či neúspěšnosti života. Oba typy sebevraždy souvisí s vyvázáním jedinců ze společnosti; z lidských vztahů či hodnotových systémů. Čím větší izolace a odcizení, tím vyšší pravděpodobnost sebevraždy, která bývá osamělým a soukromým aktem.

Fatalistická (3) sebevražda je oproti tomu způsobena přemírou hodnotové regulace ze strany malé a od okolí uzavřené skupiny. Indoktrinace vede k rozplynutí osobnosti, ke ztrátě kritického myšlení, disciplíně a konformitě vůči ideovému systému či charismatickému 
vůdci (např́iklad hromadné sebevraždy sektářů). Altruistickou (4) sebevraždu naopak charakterizují silné vazby jedince na společenství (vojenská jednotka, národ), kdy jsou zájmy celku nadřazovány zájmům osobním. Čím větší připisuje komunitě hodnotu, tím ochotněji pro ni přinese obět. Obrana okupované komunity má vyšší smysl. Schvaluje-li pak komunita [podle Pape 2006: 171-176] skrze mučednický kult obět v podobě sebevražedné mise, naskýtá se altruistům př́ležitost obětovat se pro vlast. A stát se hrdinou národa a od komunity posmrtně získat řadu poct a ocenění.

Altruistickým motivem je tedy organizacemi a komunitou konstruovaný kult mučedníkủ. Potenciálním teroristům signalizuje hodnotu, prestiž a sociální uznání mučednictví. Diskurz mučednictví přitom pracuje s trojstupňovou argumentací ospravedlňující sebevražedné akce. Za prvé, mučednictví není cílem samo o sobě. Jde jen o prostředek k dosažení vyššího cíle, jímž je ochrana komunity a ukončení okupace. Pokud by sebevražedné útoky neměly šanci okupaci ukončit, nebyly by ospravedlnitelné. Šlo by o zbytečné mrhání životy. Za druhé, nepřítel je příliš silný, nelze se mu účinně postavit jinak. Sebevražedná kampaň je krajní volbou poté, co bylo vyzkoušeno vše ostatní. Za třetí, zdánlivě silnější neprrítel je křrehký a zranitelný, terorem ho lze porazit.

Nejde tedy o únik před osobními problémy jako v případě sebevraždy egoistické či o hodnotovou dezorientaci jako u anomické. Oproti sebevraždě fatalistické existuje svoboda volby účastnit se jako dobrovolník mise. A zatímco fatalistické sebevraždy od většinové společnosti izolovaných sektářů majorita nerespektuje a odmítá, altruističtí sebevrahové jsou naopak lidé vzešlí ze středu komunity. Jsou jí podporovaní a následně i oslavováni jako hrdinové hodní následování. Jaké empirické doklady pro svá tvrzení Pape použíá?

Za prvé, data Světové zdravotnické organizace ${ }^{13}$ nepřímo ukazují, že sebevražedný terorismus nemá nic společného s běžnou sebevražedností (egoistická, anomická). A tedy ani s nejčastějšími motivy sebevražd. S výjimkou Tamilů totiž pozorujeme ve všech komunitách, z nichž se útočníci rekrutují, nízkou a celosvětově podprůměrnou sebevražednost. Nejvyšší sebevražednost vykazuje východní Evropa, leč prosta sebevražedného terorismu. Muslimské společnosti naopak nejnižší14. A zatímco zde v posledních dvaceti letech sebevražedný terorismus narůstá, sebevražednost zůstává nízká15.

Za druhé, zatímco charakteristickým rysem běžného sebevraha je sebeusmrcení o samotě, část sebevražedných misí (v průměru 46 \%) se odehrává v tandemu nebo v koordinované skupině, která sleduje společný cíl, sdílí kauzu komunity a vyžaduje vzájemnou pomoc, spolupráci a podporu spolubojovníků připravujících se na smrt. V týmu například útočí 89 \% atentátníků al-Kajdy, 73 \% Čečenců, 64 \% Tamilů a 20 \% Palestinců či Libanonců, což neodpovídá „privátnosti“ egoistické sebevraždy. Za třetí, sebevraždám předchází letargie, zabrání do osobních problémů a nezájem o ty celospolečenské. Není důvod, proč by měl jedinec toužící po co nejjednodušším konci podstupovat náročnou přípravu na misi s nejistým výsledkem, jež sleduje řešení celospolečenského problému.

13 World Health Statistics Annual [1999].

14 Rekordmanem je Rusko či Polsko (se 70, resp. 24 sebevraždami na 100 tisíc obyvatel ročně). Oproti tomu v Egyptě, Jordánsku, Sýrii či Íránu jde o jeden případ na 100 tisíc obyvatel. Světový průměr je 11-15 na 100 tisíc [Pape 2006: 182]. Nezdá se mi pravděpodobné, že by sebevražedný terorismus představoval substitut sebevražednosti. Frekvence výskytu obou jevů má jiné měřítko: k sebevraždě každoročně sáhne jeden ze 100 tisíc muslimů, k sebevražedné misi se přihlásí jeden z 15 milionů.

15 Za druhé palestinské intifády došlo k nárůstu sebevražedných útoků za poklesu i tak nízké sebevražednosti. 


\section{Sociologický portrét sebevražedného teroristy}

Jestliže jsou sebevražedné atentáty děsivé a vybočující z normálu, jsou nelidští a mimo normál i jejich pachatelé? Nikoliv. Pape se hlásí k tezi H. Arendtové [1996] o „banalitě zla“: nacista Eichmann nebyl bestií, ačkoliv sehrál klíčovou roli při bestiálním vyvraždování. Ztělesňoval průměrného a zaměnitelného jedince zodpovědně plnícího přidělený úkol. Teroristé také nebývají fanatici toužící po mučednictví jako vstupence do ráje. Ani nezralí a manipulovatelní nevzdělanci či chudí a neúspěšní nezaměstnaní bez perspektivy.

Tyto stereotypy pochází z raných a dosud citovaných studií sebevražedného terorismu libanonského Hizballáhu [např. Reich 1990]. Avšak Pape [2006: 199-216] se domnívá, že závěry byly vyvozeny předčasně, bez dostatku dat. Autor naopak ukazuje, že z celkem 41 sebevrahů útočících pod hlavičkou Hizballáhu, zastřešujícího spektrum organizací, představovali $8 \%$ křest̉ané, $71 \%$ sekulární levice (komunisté, sekulárně-nacionalistický Amal či Baas, Avantgarda arabských křest̉anů Libanonu) a jen 21 \% fundamentalisté z Islámského džihádu. Ideologickou heterogennost teroristů sjednocoval jen odpor k okupaci, přičemž měli nadprůměrné vzdělání (75 \% středoškolské nebo vysokoškolské).

Podobně vypadá i socioekonomický status subsouboru všech arabských teroristů z let 1980-2003 ${ }^{16}$. Jen 10 \% z nich absolvovalo pouze základní školu. V arabské dospělé populaci však bylo v daném období lidí s takto nízkým vzděláním v průměru $40 \%$. Stejně tak $54 \%$ teroristů mělo stř̌edoškolské nebo vysokoškolské vzdělání, průměr v populaci byl $15 \%$. Teroristé tedy vykazují vyšší vzdělání než je běžné ve společnostech, z nichž se rekrutují. Pape se domnívá, že díky vzdělání jsou politicky dobře informovaní a uvědomělí. S větší pravděpodobností se proto zapojují do politiky, a to včetně ozbrojeného odporu proti okupaci. V př́ípadě ekonomické aktivity je situace obdobná. Pouze $17 \%$ teroristů bylo chudých a dlouhodobě nezaměstnaných. Avšak v populaci bylo takových lidí $30 \%$. Naopak celých 76 \% teroristů patřilo ke kvalifikovaným dělníkům nebo středostavovským profesionálům. Průměr běžné populace přitom byl $50 \%{ }^{17}$. Opět tedy nešlo o outsidery.

Podobně vypadá i profil dalších teroristů ${ }^{18}$. Průměrný věk je 23 let, avšak věková variabilita je vysoká. 13 \% teroristů bylo velmi mladých (15 až 18 let). Avšak 32 \% naopak starších 24 let, přičemž nejstarší atentátnici z Čečenska bylo 52 let. Stejně tak se liší průměrný věk u jednotlivých organizací: Hizballáh (21 let), Tamilští tygři a Palestinci (22), PKK (24), al-Kajda (27) a Čečenci (30). Sebevražedný terorismus tak není dominantně dílem př́liš mladých. A tedy nezralých, impulzivních, nezkušených a staršími charismatickými vůdci snadno manipulovatelných. Nejde ale ani o čistě mužskou záležitost: $15 \%$ atentátníků byly ženy. Genderová variabilita mezi organizacemi je však též vysoká: v al-Kajdě ženy nenajdeme a mezi Palestinci jde o 5 \%. Avšak mezi Libanonci $16 \%$, Tamily 20 \%, Čečenci $60 \%$ a Kurdy $71 \%$. Variabilní je i ideové pozadí teroristů: 43 \% se hlásí k náboženským skupinám, 57 \% k sekulárním ideologiím (100\% u Tamilů či Kurdo̊, ale také většina Libanonců a významná část Palestinců). Pape dále odhaduje, že až jedné třetině atentátníků okupační armáda zabila př́ibuzného (nejlépe doloženo v Čečensku a Palestině). Celkově neexistuje

${ }_{16}$ Data se však podařila kompletně dohledat jen pro 70 z celkem 232 útočníků.

${ }^{17}$ Rozdíl nebyl ani v profesním postavení sekularistů a fundamentalistů. Fundamentalisté však měli o něco vy̌šśí vzdělání než teroristé sekulární.

${ }^{18}$ Z celkem 462 sebevražedných atentátníků z let 1980-2003 se podařilo dohledat základní demografická a sociologická data různého rozsahu pro 278 až 384 z nich. 
jednoznačný demografický, ideologický a sociologický profil. Sebevražední teroristé se tedy rekrutují ze všech skupin a vrstev okupované společnosti, kterou tak do určité míry reprezentují.

\section{Kritické zhodnocení: Tři logiky terorismu}

Pape uznává, že se vynořují případy, jež se absencí jednoho z faktorů odchylují od čistého vzorce konstelace pěti faktorů. Kurdská PKK se totiž nerekrutuje z jiné náboženské tradice než Turci. Al-Kajda zase na Arabském poloostrově útočí, aniž by předtím vznikla otevřená rebelie. A iráčtí povstalci naopak proti okupantům nasadili sebevražedné útoky paralelně se začátkem rebelie, tedy ihned po invazi. Konečně Rusko se během čečenské kampaně přesunulo od demokracie k autoritářství [Pape 2010]. Kromě toho existují ještě spornější př́ípady sebevražedného terorismu vykazující charakter kampaně, aniž by je Pape zmiňoval. Např́klad sebevražedné mise (2001-dosud) tureckých marxistů z DHKP/C útočících na vládní složky a západní spojence. Absentuje zde jak náboženský rozdíl, tak pro Papea zásadní okupace [srov. BBC 2013]. Nicméně Pape připouští, že model může zastarat, pokud se sebevražedná strategie prosadí i v jiných konstelacích. Což nevylučuje vzhledem k učícímu se charakteru organizací, jež racionálně aplikují taktiku, která se osvědčila jinde a s malými náklady vygenerovala vysoký politický zisk [Pape 2006]. Vynořování nového vzorce sebevražedného terorismu a rychlé zastarávání teorie záhy po jejím vzniku ostatně indikuje také Moghadam [2006]. Další pochyby vzbudila explanační síla teorie především při aplikaci na nadnárodní terorismus al-Kajdy. Nejnověji je otázkou, do jaké míry je model relevantní pro explanaci sebevražedného terorismu na Blízkém východě i na Západě ve jménu tzv. Islámského státu. Kauzální vztah mezi okupací a sebevražedným terorismem, tvořící jádro Papeovy argumentace, se proto podle řady autorů uvolňuje [Roy 2005; Kramer 2005].

\section{Strategická logika organizací}

Strategická logika organizací racionálně reagujících na okupaci je v centru Papeova komplexního modelu. Proto se kolem ní točí také většina kritik. Za prvé, Pape [2006: 13] líčí sebevražedný terorismus jako moderní fenomén šírící se až po roce 1980. V historii se podle něj vzácně vykytovaly jen sebevražedné mise (židovští zéloti, sekta asasínů, kamikadze). Avšak Pape nespecifikuje, v čem je moderní. Nevysvětluje, proč se např́klad neuplatnil již v 19. století za shodné konstelace okupace nábožensky odlišných společností ze strany západních demokracií v éře evropského kolonialismu nejevícího ochoty vyjednávat s bouřícími se domorodými populacemi. Zmiňuje jen [Pape 2010: 331], že americká okupace Německa (1945) nevedla k odporu díky kulturní a náboženské podobnosti obou společností. Roli hrál i sdílený studenoválečný nepřítel, což byl i př́pad okupovaného Japonska. Chybí tedy analýza historického původu vztahu mezi okupací a sebevražedným terorismem. Tedy proč je „rokem nula“ právě rok 1980.

Za druhé, zpochybněna byla svého času i klíčová souvislost mezi okupací a sebevražedným terorismem. Způsob výběru vzorku totiž ovlivnil závěry, ke kterým Pape [2003] zprvu došel. V první studii totiž do databáze vybral jen př́pady s pozitivní hodnotou závislé proměnné, tedy s výskytem sebevražedné kampaně. A poté si všiml, že je všem pozorováním 
společná cizí okupace, kterou prohlásil za hlavní nezávislou proměnnou, za determinantu terorismu. Autor tak ignoroval př́ípady okupací, které v terorismus nevyústily. Jeho data tak neumožňovala falzifikaci teorie. Tedy určit existenci - a poté př́padně sílu - statistického vztahu mezi nezávislou a závislou proměnnou, mezi okupací a terorismem [Ashworth Clinton - Meirowitz - Ramsay 2008]. Na to Pape [2006] reagoval sběrem informací o všech okupacích ve sledovaném období 1980-2003 (s výskytem terorismu i bez něj) a zpřesněním teorie zavedením dalších nezávislých proměnných. Od monokauzálního vysvětlení se přesunul $\mathrm{k}$ multikauzálnímu. A na související námitky o tom, že prokázaný statistický vztah ještě není věcnou kauzalitou, odpověděl kvalitativním rozborem diskurzu teroristických organizací a podrobnými př́padovými studiemi stopujícími historickou dynamiku a časovou následnost jednání aktérů [zejména Pape 2010].

Za třetí, zásadním problémem zůstává všeobsáhlá definice okupace. Ta je natolik flexibilní, že dle kritiků vždy spolehlivě nahlédne veškerý sebevražedný terorismus jako reakci na „okupaci“ [Moghadam 2006]. Je natolik široká, že se do ní vejdou nesouměřitelné př́íklady: americká „okupace“ Saúdské Arábie bez místních obětí, izraelská invaze do Libanonu s 20 tisíci obětí i ruská okupace Čečenska s 50 tisíci mrtvými [Kramer 2005]. Pape navíc směšuje reálnou objektivní okupaci se subjektivní percepcí okupace, která je pro něj určující. Jako analytik tak přebírá pohled teroristických organizací či okupovaných komunit. Aby byl schopen vysvětlovat geografickou a historickou expanzi sebevražedného terorismu, musí definici okupace stále rozšiřovat. $V$ př́padě al-Kajdy se např́ílad blíźí jejímu pohledu na americkou „okupaci“, pod kterou řadí nejen vojenské, ale také kulturní, náboženské, ekonomické a především politické vměšování v muslimském světě. Al-Kajda to vydává za ponižení a smrtelné ohrožení islámského světa, kdy se opakují křižácké výpravy a kolonialismus. Pape [2006: 109] končí u toho, že „,americká vojenská př́tomnost“ existuje všude tam, kde „Spojené státy garantují bezpečnostní záruky, k jejichž vynucování jsou připraveny použít i vojenskou sílu“. Tedy i v zemích, kde není americká armáda př́ítomna. Jenomže v éře, kdy jsou USA globálním hegemonem, platí takto flexibilní vymezení pro většinu planety. Jestliže tedy Amerika „okupuje“ celý svět, kdekoliv dojde k sebevražednému terorismu, lze ho vysvětlovat jako reakci na okupaci. Domnívám se, že ani Papeovo [2010] nejnovější řešení rozlišující prrimou a nepřímou (nap̌r. intervence etiopské či pákistánské armády vedené na popud USA) okupaci problém bezbřehé definice neřeší.

Za čtvrté, slabinou zpochybňující základní Papeovo východisko o racionální strategii organizací zůstává spor o efektivitu kampaní. Např́iklad Moghadam [2006] tytéž kampaně hodnotí odlišně a namísto $54 \%$ účinnosti uznává jen $24 \%{ }^{19}$. Moghadam totiž zpochybňuje, že Pape do analýzy efektivity zařadil jen kampaně k roku 2003 ukončené (13), nikoliv ty probíhající (5). Tvrdí, že čtyři probíhající kampaně (al-Kajda, Čečensko, Kašmír a Palestina za druhé intifády) dokazují svůj neúspěch již dlouhou dobou trvání. Kromě toho lze prý hodnotit tři $z$ již ukončených kampaní jako úspěšné jen $s$ „velkou dávkou fantazie“. Např́klad k propuštění šejcha Jasína z izraelského vězení nevedla série atentátů Hamásu ale diplomacie USA a Jordánska, které prosadilo výměnu Jasína za agenty Mossadu. Stejně tak stažení Izraele z okupovaných území prý proběhlo dle dohod z Osla (1993). A Izrael poté pozatýkal 400 bojovníků Hamásu, což neodpovídá chování zastrašené vlády.

${ }^{19}$ A dokonce jen $12 \%$ efektivitu $\mathrm{z}$ hlediska jednotlivých útoků; část neúspěšných kampaní totiž sestává $\mathrm{z}$ většího počtu nikam nevedoucích útoků. 
Navíc deklarovaným cílem Hamásu není vynucování ústupků, ale torpédování mírového procesu.

Nicméně problému (ne)efektivity si je Pape [2010] vědom, později hovoří o „limitovaném donucení" nebo dokonce o relativní efektivitě dané tím, že ostatní metody odporu jsou ještě méně účinné. Efekt teroristických kampaní je navíc obtížné odlišit od efektu dalších paralelně probíhajících forem odporu. Jde o starý metodologický problém teorií chápajících terorismus jako racionální strategii [srov. Fromkin 1975]. Rozdílně interpretovány mohou být v souvislosti s hodnocením efektivity také motivy kampaní. Těžko pak hodnotit efektivitu prostředků, když není shoda, co byl jejich cíl. Pape např́klad vykládá palestinské útoky z 90. let jako snahu vytlačit okupanta. Avšak většinová literatura [Kepel 2002; Laurens 2013] jako cynicky kalkulované torpédování mírového procesu. Nebo jako pomstu za šokující útok židovského osadníka B. Goldsteina v Hebronu [Juergensmeyer 2008; Brym 2007] či jako důsledek vnitropolitického konfliktu jednotlivých odbojových organizací o přízeň palestinské veřejnosti, protože sebevražedná kampaň proti Izraeli vyvrcholila v momentě, kdy se vedení Hamásu i OOP vrátilo z exilu a zintenzívnil jejich vzájemný boj o politickou dominanci [Bloom 2005]. M. Kramer [2005] jde dokonce tak daleko, že výsledkem sebevražedné kampaně Palestinců byl pravý opak národního osvobození a ukončení okupace: zesílení izraelské okupace, stavba bezpečnostní zdi a pád mezinárodních sympatií. Pokud ovšem kampaně nejsou - at již z jakéhokoliv důvodu - prokazatelně efektivní, přestávají být také racionální, čímž se hroutí hlavní východisko teorie.

Za páté, jakkoliv lze Papea řadit k teoretikům racionální volby a k teoretické tradici pracující s předpokladem racionality teroristických organizací, dle mého názoru si osvojil její dosti rigidní variantu. Ta je založena na představě neustálého poměřování nákladů a výnosů plynoucích ze setrvání u daného způsobu jednání nebo naopak plynoucího ze změny jednání. Tuto kalkulaci přitom provádí jak teroristická organizace, tak také vláda okupanta. Pape se tak blíží pojetí teroristické strategie načrtnuté Friedlandem a Merarim [1985]. Podle nich je terorismus náhodně mířeným násilím potenciálně ohrožujícím kohokoliv z nepřátelské skupiny. Cílem je prosadit agendu a požadavky teroristické organizace do povědomí lidí, kteří ji dosud ignorovali. V atmosféře stupňovaného strachu pak mají vystrašení lidé vytvářet tlak na vládu a požadovat splnění požadavků teroristů. Klíčová je přitom disproporce mezi přehnaným subjektivním vnímáním hrozby a její objektivní reálností, jež je vždy nižší. Přitom „cílovou skupinou“ terorismu je vystrašená veřejnost, nikoliv jeho oběti. Také podle Horgana [2005] jde o promyšlenou formu psychologického boje. Takto př́močaře se terorismu podařilo dosáhnout jednoho ze svých historicky prvních úspěchů, když vláda Velké Británie unavená guerillovou válkou a teroristickou kampaní uznala nezávislost Irska (1921). Slabinou strategie jsou ale možné bumerangové efekty. Tedy vyvolání opačného než zamýšleného účinku [Fromkin 1975]. To Pape připouští, když vysvětluje neúspěch a nepopularitu sebevražedných kampaní (PKK, Hamás) požadujících propuštění vězněných vůdců [Pape 2006]. Navíc v „cílové skupině“ je daleko obtížnější dlouhodobě atmosféru strachu udržet, než ji krátkodobě vyvolat. Dlouhodobost tlaku je však pro politickou změnu stěžejní [Friedland - Merari 1985]. Konečně, úspěch teroru je závislý na tom, zda tlaku vystavená vláda začne hrát hru vnucovanou teroristy. Politická změna totiž závisí na krocích silnější strany konfliktu. Proto se vlády čelící terorismu snaží o zdrženlivost a neakceptování hry dle vnucovaných pravidel [Fromkin 1975]. Tento rys nese většina neúspěšných kampaní popisovaných Papem, aniž by to však autor reflektoval. 
Pokud jde o metodologické ukotvení rozboru strategické logiky, autor začíná kvantitativní statistickou analýzou makroúrovně států. Tedy mapováním typických charakteristik zemí, z nichž teroristické organizace s vyšší pravděpodobností teroristy rekrutují. A mapováním charakteristik zemí, na jejichž cíle organizace častěji útočí. Obdobně postupuje také Alan Krueger [2007: 53-82], když analyzuje odlišnou databázi mezinárodního terorismu z let 1997-200320, přičemž ale dochází k nápadně shodným výsledkům. Konzistentně s Papem ukazuje, že útočníci s vyšší pravděpodobností nepocházejí z chudých zemí, ani ze zemí s většími nerovnostmi nebo nižší vzdělaností [srov. podobně vedené analýzy Piazza 2006; 2007; 2008]. Také se s vyšší pravděpodobností nerekrutují ze zemí konkrétní náboženské tradice, tedy ani z těch muslimských [srov. Krueger - Laitin 2003]. V souladu s Papem je i zjištění, že roli naopak hraje náboženský rozdíl země původu útočníka a země, na kterou se útočí. Náboženský rozdíl je navíc statisticky nejsilnější pro podmnožinu terorismu sebevražedného. Teroristé se dále častěji rekrutují z nedemokratických zemí s nízkou úrovní politických práv a občanských svobod [srov. Abadie 2006]. Terčem jsou naopak o něco častěji země demokratické, s vysokou úrovní práv a svobod občanů. Také tato konstelace dle mého názoru odpovídá Papeovým nálezům: doma sebevíce demokratický okupant ve snaze kontrolovat okupovanou populaci se svými kontrolními stanovišti a raziemi nakonec vytvoří nedemokratickou okupaci, když omezuje svobody pohybu, shromažd’ování, sdružování či slova, vyznání a projevu, přičemž dosazuje loajální okupační správce, jež nereprezentují celou populaci, nýbrž jen její určitý konfesijní, etnický, kmenový či regionální segment, přičemž okupační vojáci i jejich operace bývají vyňaty z právní jurisdikce země, a nemusí se tak řídit místními zákony a podrobovat se zdejším soudům, takže o právním státě a rovnosti před zákonem nemůže být řeč. Krueger dále identifikuje vzorec, kdy s větší pravděpodobností dochází k útokům proti zemím, jež okupují jiné státy, přičemž se naopak země okupované mírně častěji stávají zdrojnicí teroristů ${ }^{21}$. Konečně, konzistentní s Papem je i geografický rozměr mezinárodního terorismu, který je přes všechny módní teze o globalizaci teroru nadále spíše jevem lokálním. Celých 88 \% analyzovaných útoků mezinárodního terorismu se totiž odehrálo v zemi původu útočníků, kteří u sebe doma útočili na cíle reprezentující cizí zemi (ambasády, firmy, letadla). Jestliže se teroristé vydají do zahraničí, útočí nejčastěji u sousedů. Pravděpodobnost útoku na vzdálenější státy s rostoucí geografickou vzdáleností prudce klesá, přičemž útoky z 11. září 2001 jsou jevem ojedinělým, oněmi Papeovými „černými ovcemi“22. Oba autoři konvergují, když terorismus chápou jako politické jednání. Jako radikální formu hlasování prosazujícího se za radikálních

20 Používá vícenásobnou regresi. Vztahy závislé a nezávislé proměnné tak platí i po „očištěni“ od vlivu dalších kontrolovaných proměnných. Definice terorismu je oproti Papeovi užší: útoky na civilní cíle, které musí mít mezinárodní charakter díky účasti teritoria či občanů více než jedné země (vypadává tak např́iklad terorismus v Palestině, kterou chápe za součást Izraele).

${ }^{21}$ Pro vztah mezi názory veřejného mínění na zahraniční politiku dané velmoci a výskytem terorismu směřovaného proti ní viz [Krueger - Maleckova 2009].

22 Vzorec platí i pro země původu teroristů dopadených v Iráku. Protiamerické povstání bylo primárně domácí (přes 90 \% povstalců Iráčané), zatčeno bylo ale též 311 teroristů z 27 států (nejvíce Egyptanů, jež však v Iráku mnohdy žili jako hostující dělníci dlouho před válkou, a Syřanů, kdy ale mohlo jít o jiné státní příslušníky přes Sýrii jen přicházející, a proto se syrskými doklady). Roli zde hrála vzdálenost od Bagdádu. Terorismus tak byl regionálním jevem, rekrutoval lidi z okolních, převážně muslimských zemí. Převažovali povstalci z autoritářských států s nízkou úrovní práv a svobod. Častěji šlo o země bohatší a sociálně rozvinutější, přičemž míra vzdělanosti či sociálních nerovností neměla statistický vliv [Krueger 2007: 85-96]. 
okolností (okupace, autoritářský režim); jako pokračování politiky jedinými dostupnými prostředky.

Pape se ve druhém kroku opírá o kvalitativní metodologii. Postupuje jako M. Mendel [2008; 2010] nebo G. Kepel [2008], když s pomocí obsahových analýz mediálních výstupů či programových textů organizací rekonstruuje jejich vidění světa a způsob, jakým komunikují navenek směrem k publiku. Papeovi se jedná především o tematizaci legitimizace vztahu mezi okupací a terorismem, který je v textech organizací deklaratorně postulován jak směrem k okupantům, tak také směrem dovnitř do vlastní komunity. Takto také odkrývá strategické uvažování organizací skrze související témata, jako je efektivita odporu, racionální kalkul, učení se od jiných organizací či hodnocení zranitelnosti okupanta. Pape s pomocí kvalitativní metodologie ukazuje, že se v př́padě okupace a terorismu nejedná o pouhou statistickou souvislost. Nýbrž o prŕčinnou kauzalitu, když dokládá, jak na okupaci mobilizační diskurs teroristických organizací reaguje. Podobný cíl sledují i podrobné případové studie sebevražedných kampaní. Pape zde postupuje jako Introvigne [2003] při rozboru Hamásu nebo Bergen [2002] či Atwan [2012] při rozkrývání sebevražedného terorismu al-Kajdy. Zabývá se historií vzniku organizací a jejich sebevražedných kampaní, ideologií, vůdci a zejména podrobně stopuje dynamiku konfliktu a používaných metod boje.

\section{Sociální logika komunit}

Za klíčové pokládám, že Pape ignoruje desekularizaci či re-politizaci náboženství, ke které celosvětově dochází od 70. let 20. století a v sociální teorii je reflektována kritikou tzv. sekularizační teze [viz Kepel 1996; Lužný 1999; Halík 2003]. Náboženství se ve veřejné sféře prosazuje ve stejném období, kdy se rodí a rozmáhá sebevražedný terorismus. Časová souslednost ještě není kauzalitou, okupované komunity však mohou být díky náboženskému obrození více receptivní vůči konstruování kultu mučedníků, náboženské démonizaci nepřítele, legitimizaci násilí s pomocí náboženství nebo se mohou více obávat odlišné víry okupanta.

Touto rolí náboženství v komunitách podporujících terorismus se celoživotně zabývá např́iklad M. Juergensmeyer [1993, 2000, 2008; srov. Černý 2009, 2010]. A právě na pozadí celosvětově se šírící náboženské revolty proti sekularizmu dochází ke střetu dvou typů nacionalismů: nastupujícího nacionalismu náboženského a zdiskreditovaného a zkorumpovaného nacionalismu sekulárního (primární nepřítel). Ten navíc mívá vnějšího spojence v podobě okupanta: USA, Indie či Ruska (sekundární nepřítel). Oba autoři tedy chápou nacionalismus jako hybnou politickou sílu, Juergensmeyer si však všiml, jak se nacionalismus nově prolíná s náboženstvím. Za klíčové také oba autoři pokládají způsob, jakým komunity interpretují svět. Nikoliv pouze to, jak interpretují své náboženství. Prosadí-li se podle Juergensmeyera v komunitě interpretace reality v duchu tzv. kosmické války, umožní to nábožensky ospravedlnit použití násilí jako obranu. Konflikt je zasazen do transcendentálního rámce: jako součást metafyzického a celovesmírného střetu dobra a zla nebo jako pokračování legendárních historických bitev příslušníků dané náboženské tradice. Juergensmeyer [2008: 258] se na Papea explicitně odvolává, když souhlasí, že náboženství samo není př́ičinou násilných konfliktů. Spíše je vplétáno do již probíhajících konfliktů v situacích, kdy sílí pocit ohrožení vlastního teritoria či kultury. Například ze strany cizí moci. Oba autoři tak náboženství chápou jako jednu z více nezávislých proměnných. 
Metodologickým východiskem je na této rovině analýzy Papeovi kvalitativní obsahová analýza, když zachycuje způsob konstrukce mučednictví a důraz, jaký je kladen na náboženský rozdíl a ohrožení komunity ze strany kulturně odlišného okupanta. Vypomáhá si ale také kvantitativní statistickou analýzou úrovně komunit, když zkoumá data z výzkumů rozkolísaného veřejného mínění týkajícího se okupace, sympatií k teroristickým organizacím a ospravedlnitelnosti sebevražedného terorismu. Snaží se tak identifikovat názorové profily sympatizantů teroristických organizací - a tedy potenciálních rekrutů či podporovatelů - $\mathrm{z}$ širší komunity. Postupuje přitom jako další analytici veřejného mínění vůči terorismu: od klasické pionýrské práce Lernera [1964] až po rozbor sociologických šetření Gallupova ústavu [Esposito - Mogahed 2007; Krueger - Maleckova 2009] či dat Pew Center [Shafiq - Sinno 2010].

\section{Individuální logika a sociálně-demografický profil teroristů}

Za prvé, Pape pracuje s Dürkheimovou typologií sebevražd deduktivně. Implicitně předpokládá, že čtyři teoretické typy vyčerpávajícím způsobem obsáhnou celé univerzum sebevražedných motivů. Jestliže poté vylučovací metodou tři z nich eliminuje, uzavírá, že sebevražedný terorismus spadá pod zbývající altruistický motiv. Alternativní teorie sebevražednosti se však jeví podobně relevantní. Např́klad teorie nápodoby (copycat suicide) vysvětluje sériové sebevraždy jako důsledek způsobu mediální prezentace sebevražd a vysvětluje, proč se sebevraždy objevují ve shlucích, kdy jedna záhy inspiruje sérii dalších. Tato pravděpodobnost se zvyšuje, čím prestižnějšího uznání se jí dostane a je-li tato mediální pozornost opakovaná; jedná se o sebevraždu celebrity nebo někoho, s kým se lze identifikovat; upozadí se zmínky o negativních souvislostech (bolesti a utrpení); upozadí se zmínky o alternativách. Tyto vlivy jsou přitom silnější mezi teenagery než dospělými [Phillips - Cartensen 1988]. Toto pojetí podle mého názoru vysvětluje vztah mezi konstrukcí mučednického kultu na rovině komunity a motivy potenciálních teroristů na rovině individuální. Proces ústí v časté situace, kdy organizace čelí vyšší poptávce dobrovolníků, než mohou uspokojit [srov. Nasra 2001].

Za druhé, problémem může být podcenění role náboženského fundamentalismu. Moghadam [2006] totiž upozorňuje na problém sporných definic, kdy počáteční vymezení pojmů vede k systematicky zkreslenému souboru dat a následně i zkresleným teoretickým výsledkům. Pape tak nadhodnocuje podíl sekulárních teroristů a podhodnocuje podíl fundamentalistů. Pokud by totiž respektoval většinové definice terorismu jako útoků na civilisty, nikoliv uniformované složky, relativní váha Tamilských tygrů by se ve vzorku snížila (polovina útoků mírí na armádu Srí Lanky). Naopak relativní váha Hamásu by vzrostla, protože častěji útočil na civilisty ${ }^{23}$.

Základním metodologickým východiskem je Papeovi na úrovni individuální logiky kvantitativní statistická analýza identifikující mikroúroveň pachatelů a jejich typických sociodemografických či ideologických profilů. Podobně postupují např́íklad Krueger a Malečková [2002] či Bergen a Pandey [2006]. Také tito autoři si všimli, že se teroristé

23 Podobně Pape kvůli své definici podhodnocuje váhu terorismu al-Kajdy, když směšuje teroristické „incidenty“ a „útoky“. Simultánní útoky představují specifickou „obchodní značku“ al-Kajdy, Pape je ale počítá jako jeden incident (například 11. září bylo jedním incidentem sestávajícím ze čtyř útoků). Relativní váha al-Kajdy je pak podhodnocena. Sekulární Tamilové však též používají simultánní útoky a zkreslení vyruší [Moghadam 2006]. 
rekrutují spíše ze středu komunit. A přitom je jejich sociologický profil relativně variabilní a do určité míry tak tyto komunity reprezentuje [srov. Ibrahim 1980; Juergensmeyer 2000; Sageman 2004].

\section{Závěr}

Pape přichází s eklektickou teorií sebevražedného terorismu pracující s představou tři logik a pěti explanačních faktorů. Tři relevantní roviny sociální reality se řídí vlastními logikami: strategická a racionálně kalkulovaná logika teroristických organizací hledajících nejefektivnější způsob boje a mobilizujících podporu komunit; sociální logika ohrožených komunit nabízejících organizacím a jejich kampaním podporu; individuální logika altruistických jedinců rekrutujících se z těchto komunit, nabízejících svým komunitám nejvyšší obět a organizacím vlastní životy. Mezi pět explanačních faktorů tvořících konstelaci nutnou pro zrod sebevražedné kampaně patří: existence cizí okupace; již probíhající násilný a mocensky asymetrický odpor vůči této okupaci; neochota okupanta jednat; demokratický charakter okupanta; náboženský rozdíl mezi okupantem a okupovanou komunitou zvyšuje pocit ohrožení. Nejde tedy o teorii monokauzální, nýbrž multikauzální. Avšak moment okupace lze pokládat v Papeovu rozboru za dominantní. Proto teorii řadíme k zavedené teoretické tradici, jež terorismus vysvětluje jako racionálně kalkulovanou strategii určenou k prosazování politických cílů v mocensky asymetrickém konfliktu se silnějším oponentem.

Při analýze organizační logiky se Pape implicitně opírá právě o východiska teorie racionální volby. Zřetelně je zde ovlivněn svým předchozím výzkumem leteckého bombardování jako (ne)efektivního prostředku dosahování politických cílů. Nikoliv podobně uvažujícími badateli na poli výzkumu terorismu. Při analýze sociální logiky komunit se přesouvá k sociálnímu konstruktivismu, když zdůrazňuje klíčovost subjektivní interpretace objektivní reality, jež se v okupované komunitě prosadí. Konečně, při analýze individuální logiky čerpá ze strukturalismu v podání Émila Durkheima, když se při analýze sebevražd opírá o vysvětlení pracující s představou př́liš silné, nebo naopak př́liš slabé regulace jedince ze strany sociálních či hodnotových struktur. I přes tento eklektismus působí výsledná teorie sebevražedného terorismu koherentně, protože každá z použitých teoretických tradic je aplikována $\mathrm{k}$ analýze tří relativně samostatných rovin sociální reality.

Soudržnosti originální a komplexní teorie pomáhá, že je vybudována postupně a na solidním základě původního a neobyčejně rozsáhlého empirického výzkumu. Na jeho počátku byla autorem vytvořená databáze sebevražedného terorismu. Pape poté postupně využil čtyři metodologické přístupy, jež se v empirickém výzkumu determinant terorismu nejčastěji uplatňují. Papeova vstupní analýza vyšla z databáze sebevražedných útoků a z jejího statistického vztažení k (makro)charakteristikám států či regionů, z nichž se nejčastěji rekrutují útočníci. A ze vztažení k charakteristikám států, na jejichž cíle se naopak nejčastěji útočí. S pomocí této kvantitativní metodologie byl předběžně identifikován faktor okupace, demokracie a náboženského rozdílu. Pomocnou argumentaci poté poskytla databáze biografických, ideologických a sociodemografických profilů sebevražedných atentátníků. Tedy statistická analýza mikroroviny problematiky. Takto byla především vyvrácena častá klišé o roli chudoby, nevzdělanosti či náboženského fanatismu. V dalším kroku Pape využívá kvalitativní analýzu diskurzu, aby doložil, že dosud identifikovaná 
statistická souvislost je také věcnou kauzalitou. Zde především ukazuje, jak se v reakci na okupaci konstruuje obraz kulturně cizího nepřítele, pocit ohrožení komunity, hodnota vlastní kultury a především kult mučednictví a s tím související ospravedlnění tabuizované vraždy a sebevraždy jako ospravedlnitelné sebeobrany a oběti. Pape nakonec předkládá řadu podrobných případových studií sebevražedných kampaní, na kterých svá obecná zjištění přesvědčivě ilustruje, když rozkrývá dynamiku konfliktů a kauzální mechanismy, jež se při nich uplatňují.

Čtyři metodologické strategie jsou přitom ve výzkumech terorismu dlouhodobě odzkoušené a úspěšně praktikované řadou zavedených autorů, kteří se na bádání danou metodou celoživotně specializují. Pape je ve věci metodologie výjimečný tím, že jako jednotlivec postupně používá mimořádně široký repertoár výzkumných metod, což bývá doménou badatelských týmů. Skutečně originální je pak jeho výsledný teoretický model. Jeho dílčí stavební kameny jsou přitom konzistentní s rozsáhlou a empirickým výzkumem podloženou literaturou. Jak s tou, která vrší poznatky o tom, s čím vším terorismus oproti častým hypotézám nesouvisí. Tak také s tou, která nabízí komplexní vícekauzální vysvětlení a klíčovou roli připisuje faktorům politickým.

\section{Literatura a zdroje}

Abadie, Alberto [2006]. Poverty, Political Freedom, and the Roots of Terrorism. American Economic Review 96 (2): 50-56.

Arendt, Hannah [1996]. Eichmann v Jeruzalémě. Zpráva o banalitě zla. Praha: Mladá fronta.

Ashworth, Scott - Clinton, Josua D. - Meirowitz, Adam - Ramsay, Kristopher [2008]. Inference, and the Strategic Logic of Suicide Terrorism. The American Political Science Review 102 (2): 269-273.

Atwan, Abdel [2012]. After bin Laden. Al Qaeda, the Next Generation. New York: The New Press.

BBC [2013]. Profile: Turkey's Marxist DHKP-C, 2. února 2013. Dostupné z: <http://www.bbc.com/news /world-europe-21296893> [cit. 30. 4. 2016].

Benson, David [2014]. Why the Internet is not Increasing Terrorism. Security Studies 23 (2): 293-328.

Bergen, Peter [2002]. Svatá válka. Praha: Ottovo nakladatelství.

Bergen, Peter - Pandey, Swati [2006]. The Madrassa Scapegoat. The Washington Quarterly 29 (2): 117-125.

Berger, Peter - Luckmann, Thomas [1999]. Sociální konstrukce reality. Brno: CDK.

Bloom, Mia [2005]. Dying to Kill: Allure of Suicide Terror. New York: Columbia University Press.

Brym, Robert [2007]. Suicide bombing. Contexts 6 (4): 40-45.

CPOST [2016]. Suicide Attack Database. Dostupné z: <http://cpostdata.uchicago.edu/search_new.php> [cit. 20.3. 2017].

Černý, Karel [2009]. Anatomie náboženského terorismu a globální rebelie proti sekulárnímu (ne)řádu. Historická sociologie 1/2009: 97-121.

Černý, Karel [2010]. Mark Juergensmeyer: Nová studená válka jako globální vzpoura proti sekulárnímu „neřádu“? In. Šubrt, Jiří (ed.). Soudobá sociologie IV. Aktuální a každodenní. Praha: Karolinum, s. 308-330.

Černý, Karel [2015]. Př́ípadové studie vztahu sebevražedného terorismu a okupace: Kritická analýza př́stupu Roberta Papea. Rexter 1/2015: 1-48.

Dürkheim, Émile [1966]. Suicide: A study in Sociology. New York: The Free Press.

Eichler, Jan [2006]. Hrozba globálního terorismu a její vyhodnocování. Mezinárodní vztahy 3: 19-45.

Eichler, Jan [2009]. Hlavní aktéri globální války proti terorismu (GWOT), jejich sociální sítě, alokativní a autoritativní zdroje. Sociológia 41 (5): 457-484.

Errol Morris [2003]. The Fog of War (dokumentární film).

Esposito, John - Mogahed, D. [2007]. Who Speaks for Islam? What a Billion Muslims Really Think. New York: Gallup Press. 
Friedland, Nehernia - Ariel Merari [1985]. The Psychological Impact of Terrorism: A Double-Edged Sword. Political Psychology 6 (4): 591-604.

Friedman, Thomas [2010]. Horký, zploštělý a préelidněný. Praha: Academia.

Friedman, Uri [2016]. The Strategic Logic of Suicide Bombing. The Atlantic, March 23, 2016.

Fromkin, David [1975]. The Strategy of Terrorism. Foreign Affairs, July 1975.

Halík, Tomáš [2003]. Globalizace a náboženství. In. Mezřický, Václav (ed.). Globalizace. Praha: Portál, s. $133-147$.

Hasan, Nasra [2001]. An Arsenal of Believers. The New Yorkem, November 19, s. 36-41.

Hesová, Zora [2010]. Džihád mezi politikou a náboženstvím: Hledání logiky „islámského terorismu“. Dějiny a současnost 7: 2-7.

Hoffman, Valery [1995]. Muslim Fundamentalists: Psychosocial Profiles. In. Martin, Marty - Appleby, Scott (ed.). Fundamentalisms Comprehended. Chicago: Chicago University Press, s. 199-230.

Holland, Joshua [2015]. Here's What a Man Who Studied Every Suicide Attack in the World Says About ISIS' Motives. The Nation, December 2, 2015.

Horgan, John [2005]. The Psychology of Terrorism. London: Routledge.

Ibánez, Luis de la Corte [2009]. Logika terorismu. Praha: Academia.

Ibrahim, Saad Edin [1980]. Anatomy of Egypt's Militant Groups. International Journal of Middle East Studies 12 (4): 423-453.

Introvigne, Massimo [2003]. Hamás: Islámský terorismus ve Svaté zemi. Praha: Vyšehrad.

Jordan, Jenna [2014]. Attacking the Leader, Missing the Mark. Why Terrorist Groups Survive Decapitation Strike. International Security 38 (4): 7-38.

Juergensmeyer, Mark [1994]. The New Cold War? Religious Nationalism Confronts the Secular State. Berkeley: University of California Press.

Juergensmeyer, Mark [2000]. Terror in the Mind of God. The Global Rise of Religious Violence. Berkeley: University of California Press.

Juergensmeyer, Mark [2008]. Global Rebelion. Religious Challenges to the Secular State, from Christian Militias to al Qaeda. Berkeley: University of California Press.

Keller, Jan [1997]. Úvod do sociologie. Praha: SLON.

Keller, Jan [2001]. Dějiny klasické sociologie. Praha: SLON.

Kepel, Gilles [1996]. Boží pomsta. Křestané, židé a muslimové znovu dobývají svět. Brno: Atlantis.

Kepel, Gilles [2002]. Jihad. The Trail of Political Islam. Cambridge: Harvard University Press.

Kepel, Gilles [2004]. The War for Muslim Minds. Islam and the West. New York: Harvard University Press.

Kepel, Gilles (ed.) [2008]. Al Qaeda in its own words. Cambridge: Belknap Press of Harvard University Press.

Kramer, Martin [1990]. The Moral Logic of Hizballah. In. Reich, Walter (ed.) Origins of Terrorism. Baltimore: John Hopkins University Press, s. 131-158.

Kramer, Martin [2005]. Suicide Terrorism in the Middle East: Origins and Response. The Washington Institute for Near East Policy. Dostupné z: <http://www.washingtoninstitute.org> [cit. 20. 4. 2016].

Krueger, Alan - Maleckova, Jitka [2002]. Education, Poverty, Political Violence and Terrorism: Is There a Causal Connection? Dostupné z: <http://www.krueger.princeton.edu/references.html> [cit. 20. 4 . 2016].

Krueger, Alana - Laitin, David [2003]. Kto kavo?: A Gross-Country Study of the Origins and Targets of Terrorism. November 11, 2003. Dostupné z: <http://www.krueger.princeton.edu/references.html $>$ [cit. leden 2016].

Krueger, Alan [2004]. Misunderestimating Terrorism. Foreign Affairs 83 (5): 8-13.

Krueger, Alan [2007]. What Makes a Terroris. Economics and the Roots of Terrorism. Princeton: Princeton University Press.

Krueger, Alan - Maleckova, Jitka [2009]. Attitudes and Action: Public Opinion and the Occurrence of International Terrorism. Science 32 (5): 1534-1536.

Lake, David [2002]. Rational Extremism: Understanding Terrorism in the Twenty-first Century. International Organization, Spring 2002: 15-28.

Laurens, Henry [2013]. Orient za časů Ameriky. Praha: Academia.

Lerner, Daniel [1964]. The Passing of Traditional Society. Modernizing the Middle East. New York: The Free Press and Collier-Macmillan Limited. 
Lužný, Dušan [1999]. Náboženství a moderní společnost. Sociologické teorie modernizace a sekularizace. Brno: Masarykova univerzita.

Mearsheimer, John - Walt, Stephen [2016]. The Case for Offshore Balancing. A Superior of U.S. Grand Strategy. Foreign Affairs July/August 2016: 70-83.

Mendel, Miloš [2008]. S puškou a Koránem. Praha: Orientální ústav.

Mendel, Miloš [2010]. Džihád. Brno: Atlantis.

Merari, Ariel [1990]. The Readiness to Kill and Die. Suicidal Terrorism in the Middle East. In. Reich, Walter (ed.). Origins of Terrorism. Baltimore: John Hopkins University Press, s. 131-158.

Moghadam, Assaf [2006]. Suicide Terrorism, Occupation, and the Globalization of Martyrdom: A Critique of Dying to Win. Studies in Conflict and Terrorism 29 (8): 707-729.

Pape, Robert [1996]. Bombing to Win. Air Power and Coercion in War. New York: Cornell University Press.

Pape, Robert [2003]. The Strategic Logic of Suicide Terrorism. American Political Science Reviw 97 (3): $1-19$.

Pape, Robert [2006]. Dying to Win. The Strategic Logic of Suicide Terrorism. New York: Random House.

Pape, Robert - Feldman, James [2010]. Cutting the Fuse. The Explosion of Global Suicide Terrorism and How to Stop It. Chicago: The University of Chicago Press.

Pape, Robert [2013]. The End of Fear, The Beginning of Understanding. Dostupné z: <http://d3qi0qp55mx5f5 .cloudfront.net/cpost/i/docs/Pape-The-End-of-Fear.pdf> [cit. 20. 4. 2015].

Phillips, D. P. - Cartensen, L. L. [1988]. The Effect of Suicide Stories on Various Demographic Groups, 1968-1985. Suicide and Life-Threatening Behavior 18 (1): 100-114.

Piazza, James [2006]. Rooted in Poverty? Terrorism, Poor Economic Development, and Social Cleavages. Terrorism and Political Violence 18 (1): 159-177.

Piazza, James [2007]. Draining the Swamp: Democracy Promotion, State Failure, and Terrorism in 19 Middle Eastern Countries. Studies in Conflict and Terrorism 30 (3): 521-539.

Piazza, James [2008]. Do Democracy and Free Markets Protect Us From Terrorism? International Politics 45: 72-91.

Raděj, Tomáš [2006]. Kult mučedníka (šáhid) v islámu a sebevražedný terorismus. In. Souleimanov, Emil (ed.). Terorismus. Válka proti státu. Praha: Eurolex Bohemia, s. 249-268

Raděj, Tomáš [2010]. Sebevražedný terorismus - kult mučedníka v islámu. In. Souleimanov, Emil (ed.). Terorismus. Pokus o porozumění. Praha: SLON, s. 183-197.

Reich, Walter (ed.) [1990]. Origins of Terrorism. New York: Cambridge University Press.

Roy, Olivier [2004]. Globalized Islam. The Search for a New Ummah. New York: Columbia University Press. Sageman, Marc [2004]. Understanding Terror Networks. Philadelphia: University of Pennsylvania Press.

Shafiq, M. Najeeb - Sinno, Abdulkader. H. [2010]. Education, Income and Support for Suicide Bombings: Evidence from Six Muslim Countries. Journal of Conflict Resolution 54 (1): 146-178.

Karel Černý (* 1980) působí jako sociolog na Fakultě humanitních studií Univerzity Karlovy. Zabývá se teoriemi sociální změny, konfliktu, války a terorismu. Specializuje se na region Blízkého východu a integraci muslimů v západních společnostech. V rámci Fulbrightova stipendia (2012-2013) pobýval na Kalifornské univerzitě. Obdržel Cenu Jaroslava Krejčího, udělovanou na půdě Akademie věd (2012). Je editorem monografie Nad Evropou půlměsíc (2015) a autorem knihy Svět politického islámu: politické probuzení Blízkého východu (2012), jež rozkrývá strukturální př́činy nestability regionu. Byl hlavním řešitelem grantu GA ČR, zabývajícím se arabskými revolucemi (2013-2015). 